\title{
HOSPITAL GOVERNANCE, PERFORMANCE OBJECTIVES, AND ORGANIZATIONAL FORM
}

\author{
Leslie Eldenburg \\ Benjamin E. Hermalin \\ Michael S. Weisbach \\ Marta Wosinska \\ Working Paper 8201 \\ http://www.nber.org/papers/w8201 \\ NATIONAL BUREAU OF ECONOMIC RESEARCH \\ 1050 Massachusetts Avenue \\ Cambridge, MA 02138 \\ April 2001
}

Hermalin, Weisbach, and Wosinska acknowledge the support of the NSF (Grant SBR-9616675). We thank Ashiq Ali, Jim Brickley, Laurie Krigman, Kevin Hallock, Jonathan Leonard, Lil Mills, Raynolde Pereira, Jaime Zender, and seminar participants at Arizona, Berkeley, and Dartmouth for helpful comments. Hermalin and Wosinska also acknowledge the support of the Haas School of Business through the Harold Furst Chair and the Willis H. Booth Chair. The views expressed herein are those of the authors and not necessarily those of the National Bureau of Economic Research.

(C) 2001 by Leslie Eldenburg, Benjamin E. Hermalin, Michael S. Weisbach and Marta Wosinska. All rights reserved. Short sections of text, not to exceed two paragraphs, may be quoted without explicit permission provided that full credit, including $\odot$ notice, is given to the source. 
Hospital Governance, Performance Objectives, and Organizational Form

Leslie Eldenburg, Benjamin E. Hermalin, Michael S. Weisbach and Marta Wosinska

NBER Working Paper No. 8201

April 2001

JEL No. G3, L3, D2

\begin{abstract}
This paper studies the governance of a sample of California hospitals. We document a number of empirical relations about hospital governance: The composition of the board of directors varies systematically across ownership types; poor performance and low levels of uncompensated care increase board turnover, with this sensitivity varying by organizational type. Poor performance, high administrative costs, and high uncompensated care lead to higher CEO turnover, with these effects again varying across different organizational types. Overall, these results are consistent with the view that boards of directors of hospitals of different organizational forms are substantially different, and that these boards make decisions to maximize different objective functions.
\end{abstract}

Leslie Eldenburg University of Arizona

Michael S. Weisbach

University of Illinois and NBER
Benjamin E. Hermalin

University of California, Berkeley

Marta Wosinska

University of California, Berkeley 


\section{Introduction}

From a normative perspective, corporate governance structures exist to ensure that firms behave in an efficient—or at least second-best efficient-manner. Underlying any notion of efficiency, however, is the identity of the objective function to be maximized. With for-profit corporations, the objective function is generally assumed to be profit or value maximization. ${ }^{1}$ Indeed, this assumption is so common that it rarely warrants mention in the first place. When, however, the corporation is a non-profit organization, the choice of objectives is much more relevant, since theory is silent on non-profit objectives, and casual empiricism suggests that non-profit objectives do vary. If their governance structures serve to ensure that their objectives are most efficiently achieved, then differences in objectives should lead to differences in governance. In this paper, we examine the extent to which differences in objectives lead to differences in organizations' governance using a sample of California hospitals.

We choose hospitals because they exist simultaneously as many different kinds of organizations with different types of owners. Hospitals span profit and nonprofit, private and government ownership, and have different levels of outside financial interest (e.g., shareholders, voters, and donors). Yet despite these differences, the formal governance structure is quite similar: all hospitals have governing boards that ostensibly oversee professional managers. Although some differences exist across types, all hospitals perform the same basic services; that is, despite differences in objectives, there is an essentially common product produced under standard methods. Hence any differences in governance cannot be explained by differences in product or methods.

Our hypothesis that different objectives lead to differences in governance really encompasses three hypotheses: One, that governance matters-at least at the level we can

\footnotetext{
${ }^{1}$ For more on governance of for-profit firms, see surveys by Shleifer and Vishny (1997) and Hermalin and Weisbach (2000).
} 
observe it. If it didn't, then there would be no reason for systematic differences in governance across different types of hospitals. Two, that governance is matched to objectives; that is, one size doesn't fit all and optimal governance depends on the objectives to be accomplished.

Finally, three, that differences in governance leads to systematic differences in how organizations respond to performance measures.

Specifically, we expect to observe a number of phenomena. We expect, for instance, that different types of hospitals will have substantially different sized board of directors and that the make-up of the board, in terms of such features as proportion of non-management directors, occupations of directors - the features typically described as board composition—will also vary across hospital types. We examine these differences across different classes of hospitals in our sample and find that, indeed, boards vary significantly across hospital organizational forms.

We also expect that turnover in directors would respond differently to various performance measures across the different hospital types. By estimating the factors leading to board turnover, we potentially learn something about what the organization values. We find, for example, that poor financial performance and low levels of uncompensated care are important factors affecting board turnover. The sensitivity of board turnover to these factors varies statistically across hospital types.

Finally, we expect the actions of hospital boards to vary across the different organizational types because boards' objectives vary across these organizational types. To examine this hypothesis, we focus on the decision to replace a CEO, because that decision is generally considered one of the most important board functions. We estimate CEO turnover equations and examine the sensitivity of turnover to a number of variables, as well as how these sensitivities differ across organizational forms. As in board turnover, financial performance is an important determinant of CEO turnover. The sensitivity of turnover to performance varies across hospital types, with the strongest turnover to performance relation being for the nonprofit (other than government or religious) hospitals. High administrative costs are consistently 
related to CEO turnover, but the effect is most significant in district and teaching hospitals. In addition, uncompensated care and its components, bad debt and charity care, affect CEO turnover differentially in different types of hospitals.

Overall, we view these results as contributing to our understanding of nonprofit governance. Our results indicate that hospital boards differ substantially in character and that these boards make decisions to maximize different objective functions.

The next section reviews the literature on governance and describes our empirical approach. Section 3 describes our sample of California hospitals and presents summary statistics on this sample. Section 4 discusses our empirical approach. Section 5 presents estimates of equations predicting both board and CEO turnover and examines their implications. Section 6 is a brief conclusion.

\section{Theory of Governance}

What makes governance and its conduct difficult to study is its inherently endogenous nature. At every point in time, two forces are at work simultaneously. First, the form of governance responds to a number of factors, including the organization's performance. Second, the organization's performance is likely a consequence of how the organization is and has been governed. For instance, in Hermalin and Weisbach (1998) the board of a for-profit firm evolves endogenously over time. In their model, the board monitors the CEO and potentially replaces him. Simultaneously, however, the board's makeup is itself changing, because better-performing CEOs are "rare goods," who are able to bargain for a friendlier board. Consequently, the approach of relating conduct and contemporaneous performance is fraught with endogeneity problems and leads to empirical results that are hard to interpret.

This endogeneity problem has an important impact on the success of various approaches toward empirical work on governance. One fairly successful approach has been to examine the extent to which performance and other factors affect subsequent changes in governance. Examples include Demsetz and Lehn, 1985, Hermalin and Weisbach, 1988, 
Brickley and James, 1987, Denis and Sarin, 1999, Shivdasani and Yermack, 1999, Baker and Gompers, 2000, and Kroszner and Strahan, 2000. This literature has documented that performance does, indeed, change governance (e.g., Hermalin and Weisbach, 1988, find firm performance plays a systematic role in determining how board vacancies are created and filled).

A second approach examines the impact of governance on firm behavior. One correlate of behavior is financial performance. Admittedly, regressing financial performance on governance variables is somewhat problematic because of simultaneity problems. Nonetheless this approach has been applied with mixed success (see, for example, Morck et al., 1988, Hermalin and Weisbach, 1991, Yermack, 1997, and Bhagat and Black, 2000). Estimating the impact of governance on behavior more directly, such as subsequent control events, avoids the endogeneity problem because governance measured is prior to the control event (see, Weisbach, 1988, Shivdasani, 1993, and Brickley et al.,1994, among others). These articles generally find that the composition of the board influences observable actions associated with the control of the firm such as CEO turnover and the likelihood of subsequent takeovers. Overall, the literature on boards has substantially increased our knowledge of how governance works in for-profit firms (see Hermalin and Weisbach, 2000, for a survey of this literature).

\subsection{Governance of Nonprofits}

Although governance has engendered much ink in the economics and finance literatures, the overwhelming bulk of this attention has been on the governance of for-profit firms. In contrast, next to nothing has been has been said about the governance of nonprofits. Given that nonprofits are prominent providers in many markets, including healthcare, this lack of attention seems curious. Perhaps some of this lack of attention derives from theoretical issues that arise because non-profits don't share a single objective, such as profit maximization. Moreover, existing economic theory is not well-suited to studying the governance of organizations that appear to have multiple objectives versus a single objective. The differences between for-profit and nonprofit organizations have been documented in the little work done 
comparing governance between them. For example, Hermalin and Wallace (1994) find evidence that non-profit thrifts have more severe owner-manager agency problems, but less owner-debtor conflict, than do for-profit thrifts.

Because nonprofits typically possess multiple objectives, their decision-making resembles consumer decision-making: Both choose a bundle (goods and services in the case of the consumer; behaviors in the case of the nonprofit) subject to a constraint (a budget constraint in the case of the consumer, some production-possibility frontier in the case of the nonprofit). Unlike a consumer, however, a nonprofit is not a single decision maker, but run by many decision makers. As a stylized description of the decision-making process, we can view the board of directors as defining the organization's preferences, and management as making the decisions to maximize the objective, "utility," function defined by these preferences. The board encourages managers to make decisions consistent with their preferences by setting pay, determining promotions, or, in the extreme, by threatening dismissal. For instance, if directors prefer the hospital care for the indigent (charity care), but the actual amount of such care is small, then the directors will likely conclude that management has not honored their preferences, and they will sanction management.

Presuming that management wishes to avoid sanctions and to receive rewards, we should expect that they will simply honor the board's preferences. There are, however, two confounding issues: First, through its ability, management also defines the feasible set of alternatives. For instance, the options available to a hospital whose management is good at cost containment, but poor at human-resource management, are likely different than those available to a hospital whose management is poor at cost containment, but good at human-resource management. The former hospital—call it A for future reference—might, for example, have more resources to devote to charity care, but its quality of care could be low due to poor staff morale. The latter hospital—call it B for future reference—conversely, might offer a high quality of care, but be too financially constrained to offer much charity care. 
The second confounding issue is that the board, rather than being a single actor, is itself composed of multiple actors who likely have differing preferences. The board's decision will reflect some function of the preferences of the individual directors. Managers will desire a board made up of directors who prefer those attributes in which they are strong and care least about those attributes in which they are weak. For example, the managers of hospital B desire a board that cares most about quality of care and little about charity care, while the managers of hospital A would have the opposite desire.

These two confounding issues then have the following effects: The board, or at least a majority of its members, prefers to appoint directors who share its preferences. Management seeks the appointment of people who prefer the activities in which management excels. To the extent that both the incumbent board and management influence the appointment process, the composition (preferences) of the board could drift over time. ${ }^{2}$

Of course, the rate of drift depends on the nature of the organization. For instance, a government owned hospital (city or county) likely has pretty set preferences with respect to the level of community benefits because community benefits are, in large part, the raison d'être of the government hospital. Similarly, making money is the raison d'être of the for-profit hospital. Management that is weak vis-à-vis the hospital's raison $d$ être 'will be in trouble because there is little scope for it to influence board composition in favor of different preferences.

Empirically, what should we see? To the extent that different types of nonprofitsspecifically different types of hospitals_hold different preferences, then the factors that determine whether management—specifically the CEO-stays or goes should differ across these types. Such differences should be most consistent for types in which the board's preferences are likely fixed, such as a government hospital's board holding a preference for

\footnotetext{
${ }^{2}$ See Hermalin and Weisbach, 1998, for a theoretical examination of why future board composition will be influenced by the preferences of both incumbent directors and incumbent management.
} 
community benefits and a for-profit hospital's board holding a preference for profit. Hence, for some types, we should see a consistent relation between a given performance dimension (e.g., amount of community benefits, amount of profits) and whether the CEO keeps or loses his job.

For some types, however, preferences could be more variable. Their conduct could, then, be more influenced by the give and take between board preferences and managerial ability. For these types, then, we should expect more board composition change in response to indicators of managerial ability. Unfortunately, as outsiders, we cannot measure the preferences of the directors directly. Hence, we must use, as a proxy, changes in the composition of the board as a measure of adjustments to the distribution and nature of the directors' preferences. Similarly, we cannot directly measure managerial ability, but must use performance measures as proxies. For these hospitals, then, we should expect to see greater responsiveness of the board, as measured by changes in its personnel, to performance measures than for hospitals with more fixed preferences.

The following summarizes these arguments:

Summary of predictions about strength of relations between performance and CEO or board-personnel changes.

\begin{tabular}{|l|l|l|}
\hline & \multicolumn{1}{|c|}{$\begin{array}{c}\text { Strength of response in a } \\
\text { hospital whose type has } \\
\text { strong inherent preferences } \\
\text { (e.g., religious, for-profit) }\end{array}$} & $\begin{array}{c}\text { Strength of response in a } \\
\text { hospital whose type has } \\
\text { weak inherent } \\
\text { preferences (e.g., other } \\
\text { kinds of hospitals) }\end{array}$ \\
\hline $\begin{array}{l}\text { Effect of performance in area of } \\
\text { inherent importance, such as } \\
\text { charity care \& profitability on } \\
\text { change in CEO. }\end{array}$ & Strong & Weak to moderate \\
\hline $\begin{array}{l}\text { Effect of performance in area } \\
\text { not of inherent importance on } \\
\text { change in CEO. }\end{array}$ & Weak to moderate & Weak to moderate \\
\hline $\begin{array}{l}\text { Effect of performance in area of } \\
\text { inherent importance on change } \\
\text { in board personnel. }\end{array}$ & Weak to moderate & Moderate to strong \\
\hline $\begin{array}{l}\text { Effect of performance in area } \\
\text { not of inherent importance on } \\
\text { change in board personnel. }\end{array}$ & Weak to moderate & Moderate to strong \\
\hline
\end{tabular}


Observe that even if we don't know, ex ante, which type of hospitals have strong inherent preferences (raisons d'être) and which don't, the predictions in Table 1 can still be tested: Does strength of response for CEO turnover correlate negatively with strength of response in board personnel change?

\subsection{Organizational Form and Hospital Objectives}

A hospital's objective is likely to be a function of a number of different factors. Some of these factors probably are important in all hospitals. For example, all hospitals care about economic viability and the quality of patient care. In addition, nonprofits, religious, and government hospitals presumably value — or at least perceive a mandate to provide — charity care. Teaching hospitals place a higher weight on research and the training of new physicians than do other hospitals. Neither theory nor observation can give the precise weights assigned these factors. Nonetheless, there is likely to be systematic variation among hospitals of different types in terms of the weights they assign various factors in their objective functions. ${ }^{3}$

What, then, should we expect to be the characteristics of boards and objectives in different types of hospitals? Religious hospital boards consist of members of the church, lay members and medical personnel. Their objectives are likely to include providing a reasonably high quality of care, maintaining an operating margin that allows for reinvestment in equipment and technology, charity care, and programs that benefit the community, among other objectives.

Other nonprofit hospitals are frequently organized either by communities or by a group of physicians. Hospitals organized a group of physicians are likely to have different objectives than other nonprofit hospitals. Their boards include a larger proportion of physicians. These hospitals may value increased investment in equipment and technology more than charitable

\footnotetext{
${ }^{3}$ Brickley and Van Horn (2000) present a model in which pecuniary incentives motivate a manager of a nonprofit hospital to choose between different objectives. In the context of their model, in which incentives are provided through direct financial incentives rather than indirectly through the possibility of dismissal, differences in the weights in the objective function lead to differences in the sensitivity of pay to various objectives.
} 
services. Service departments in these hospitals are likely to provide services for their related clinics at a discount. If operating margins are reasonable, cost control may not be as important to these organizations.

District hospitals are partially subsidized by taxes, their board members are elected, and all board meetings are public. Consequently, cost containment may be a high priority for these organizations. Taxpayers expect lower charges in exchange for tax support. Accordingly, it may be more difficult for these hospitals to maintain reasonable operating margins. Decisions such as CEO compensation are made in public board meetings, leading to relatively low CEO compensation and other potential budgetary constraints on CEOs of these hospitals.

Board appointments in government hospitals are typically given to community activists or political allies who expect the hospital to provide large amounts of community benefits such as charity care. Cities and counties heavily subsidize these organizations so operating margins may be relatively unimportant (although changes in fiscal pressures on counties and municipalities could quickly change the importance of operating margins). Physicians tend not to be highly represented on these boards and, based on anecdotal evidence, many of these physicians also practice in teaching and other hospitals where they are more involved in organizational objectives.

Teaching hospital boards tend to be large and include a wide variety of members, from regents to prominent community leaders and business people. Between 1983 and 1997, Medicare's prospective payment system included a large subsidy for residents and medical education. To fund the investment in equipment and technology so important to the teaching and research mission of these organizations, high operating margins may also be valued highly. In addition, other hospitals often funnel complex charity care cases to these hospitals, and since complex patients provide practical training experience for residents, these hospitals may value charity care more than other types of hospitals. 


\subsection{Previous Work on Hospital Governance}

Brickley and Van Horn (2000) estimate the relations between CEO turnover and hospital performance and between CEO pay and hospital performance, using a sample of nonprofit hospitals between 1993 and 1995. They find that the relation between CEO turnover and hospital performance is statistically indistinguishable from that for a sample of for-profit hospitals, and that the relation between CEO pay and hospital performance is similar to previous estimates from a sample of publicly traded firms. In contrast to Brickley and Van Horn, we break down our nonprofit hospital sample by ownership type, so we are able to provide evidence about differences in objective functions among nonprofit hospitals as well as between nonprofit and for-profit hospitals. Overall, the two papers are complementary, as they find similar relations between CEO turnover and performance on very different samples of hospitals.

Other work on hospital governance and management includes Alexander et al. (1986), which finds that physician representation and voting rights on boards is higher among for-profit hospitals than others. Boeker and Goodstein (1991) find that low occupancy rates increase the likelihood of changes in board composition. Judge and Zeithaml (1992) indicate that board size, diversification, and insider representation are negatively related to measures of board involvement, while organization age and return on assets are positively related to these measures. Beekum, Stedham and Young (1998) use a 1989 survey on hospital governance by the American Hospital Association and perform cross-sectional analysis of 167 California hospitals. They find that board size and diversity are related to board emphasis on financial outcomes. Using the same data, Young, Stedham, and Beekun (2000) find that boards with independent chairpersons are more likely to adopt a formal CEO evaluation process. Young (1996/97) uses a sample of California hospitals between 1980 and 1991 and finds that insider representation is associated with less charity care (uncompensated care) among hospitals in relatively weak financial condition as well as those in highly competitive markets. 


\section{Sample Construction and Descriptive Statistics}

The American Hospital Association (AHA) recognizes a number of different types of hospitals, including for-profit, religious nonprofit, other nonprofit, hospital district, and other government. For-profit hospitals consist of privately owned hospitals, as well as hospitals that are part of a larger for-profit organization such as Columbia/HCA. Religious hospitals are owned and operated by religious orders. Other nonprofit hospitals are owned by a variety of organizations. Some of these are community hospitals set up as nonprofit corporations with a mission to serve the local community. Physician practice groups have set up nonprofit hospitals especially for their clinical community. Hospitals associated with university medical schools are also included in the other nonprofit category by AHA; however, we treat these university teaching hospitals together with other teaching hospitals as a separate category in our empirical work. Hospital districts have been organized to operate local hospitals and have the ability to impose taxes to support hospital operations. The final category, other government hospitals, includes city and county-owned hospitals.

The state of California has required hospitals that treat Medicaid patients to submit annual hospital cost accounting reports since 1976. These data include detailed cost information and annual financial statement data for all California hospitals, except federal and HMO-owned hospitals (the Kaiser Permanente system). Included in the data are names of the CEO and the governing board members, as well as the occupations of the latter. Our sample hospitals are acute-care hospitals; long-term care facilities and providers of specialized services, such as substance abuse and mental health centers, are excluded because they provide a very different set of services. ${ }^{4}$ These data are available publicly through the Office of Statewide Health Planning and Development (OSHPD).

\footnotetext{
${ }^{4}$ Other excluded hospitals specialize in only one type of treatment such as physical rehabilitation or eye disorders.
} 
OSHPD began collecting governance data in 1980, and we use data through 1996.

Table 1 presents the sample by hospital type. This sample consists of an unbalanced panel of 486 hospitals with a total of 6434 hospital-years and over 83,000 director-years. Religious hospitals contribute 581 hospital-years, other nonprofits 1873, for-profits 1959, government (city and county) 291 , district hospitals 806 , and teaching (of any ownership type) 926 -. Although, in prior healthcare studies, a ratio of residents to beds is used to indicate teaching hospitals (Young, 1994, for example), we consider teaching hospitals a separate category since all teaching hospitals, regardless of their organization type, have similar missions. ${ }^{5}$ As mentioned earlier, these hospitals benefitted substantially from Medicare reimbursement policies that subsidized medical education based on a formula that included the ratio of residents to beds. Additionally, several studies suggest that hospitals with residents are associated with higher levels of charity care (Young, 1996/97, and Buczko, 1994). Table 1 also contains data on ownership and organizational changes. For-profit hospitals undergo the most changes, with 96 ownership changes and 29 going out of business during our sample period.

Table 2 contains summary statistics (by type of hospital) of variables used in our analysis. This table suggests that CEO turnover rates are substantialy higher in for-profit hospitals and government hospitals than in other types. These data include all interim CEOs and therefore the turnover rates we report are somewhat higher than those found in other healthcare studies. Given that interim CEOs' turnover is likely to be unrelated to our independent variables, including interim CEOs in our sample simply adds noise to our dependent variable. Consequently, including them will not bias our coefficients. Excess income margins are substantially lower in government hospitals than in other hospitals, which is not

\footnotetext{
${ }^{5}$ The American Hospital Association annual survey information was used to identify teaching hospitals. These hospitals are approved by the Accreditation Council for Graduate Medical Education, are affliliated with medical schools as reported to the American Medical Association, or are members of the Council of Teaching Hospitals. Hospitals identified as teaching are frequently associated with two or three of these organizations. There are 63 teaching hospitals in our sample.
} 
surprising given that government hospitals provide by far the most uncompensated care. Forprofit hospitals have higher administrative expenses than other types, possibly reflecting higher salaries including bonuses for upper management. Similar to past studies (GAO, 1990, for example) the level of charity care is relatively small for all hospital types, except government and teaching hospitals, which provide much higher levels of charity care. Overall, it appears that there are substantial differences across organizational forms in terms of their activities and governance.

The OSHPD data includes a brief description of each director's primary occupation. We group these occupations into a number of categories. We classify CEOs and hospital administrative personnel as insiders. ${ }^{6}$ Outsiders include business people, educators, community members, homemakers and "others." While these two categories are a sufficient classification in most industrial firms (with the outsider category comprised mainly of business executives from other firms), hospitals typically have other types of directors who are neither insiders nor outsiders. Physicians and clinical directors can have different preferences than administration: for example, doctors often want more expensive equipment and are more interested in quality, while adminstrators are tend to be more concerned with cost control. Therefore, we include separate categories for insiders and medical personnel.

A number of hospitals have missing data on governance. Eight hospitals (82 hospitalyears) provide no board composition data for all years they appear in the panel. There are also 53 hospitals in which individual years of governance data are missing (total of 139 hospitalyears). Finally, there are 87 board entries with fewer than three directors reported. Because California's corporate law requires the board to have at least three members, we eliminate these observations. Ten hospitals (all members of one system) were characterized by an unusually

\footnotetext{
${ }^{6}$ One small private hospital had all board members share the same Vietnamese last name. We have assumed these board members to be insiders.
} 
large number of ownership changes, and these were deleted. These data requirements leave us with a total of 5910 hospital-years as usable board observations. Note that all these missing board observations may still be used for CEO turnover equations.

Hospitals of different organizational forms are likely to have boards of different sizes and compositions. For example, boards of religious hospitals are often quite large (see Table 3). For example, our interview with a Carondelet hospital in Tucson, AZ (not in our sample) revealed that its board has a composition that historically has been constant, made up of six lay members, six physicians, and six Sisters. Each position may turn over, but the hospital's tradition is that the number of board members in each category remains constant. Table 3 presents pooled statistics on the board of directors for our sample. When these averages are plotted across time (not reported here), there are marked differences between hospital types. These differences persist over time and are consistent with our casual observation that many hospitals have predetermined ratios for board composition. In Table 3, religious, teaching, and nonprofit hospital boards are nearly twice as large as government and district hospital boards. For-profit hospitals rely heavily on medical personnel, who comprise 35 to 45 percent of the forprofit directors. In contrast, the percentage of medical staff on government hospital boards is only about five percent. Religious hospitals have a relatively high percentage of insiders on the board, largely members of the religious orders that operate the hospitals. In contrast, for-profit hospitals have only 10 to 15 percent insiders on the board, while government hospitals appear to consist mainly of non-business outsiders (judges, city officials, police chiefs, housewives, and other community members). For-profit hospital boards include the largest percentage of business executives, however this percentage decreased following the 1984 Medicare Reform. Other nonprofit hospitals have the largest percentage of professionals such as lawyers, bankers and accountants. 


\section{Empirical Approach}

We propose to use the nature of the relationship between the board and the CEO in our sample of hospitals to explore potential differences in organizational objectives. Both the determinants and actions of the board are likely to differ across organizational forms because of these differing objectives, as well as other reasons. Our empirical analysis parallels our discussion of simultaneity since we consider the factors that affect board structure and we examine the board's actions. We first consider incremental changes to the board and the extent to which they are influenced by various factors. Secondly, we examine a critical action boards take, the decision to replace the CEO, and the extent to which this decision differs across hospital types. The goal of each approach is to reveal the organization's objective.

Our data contain three variables that are likely to be related to a hospital's objective function: excess income margin, administrative expenses, and uncompensated care. Excess income margin is defined as a ratio of gross operating and non-operating income to gross revenue. ${ }^{7}$ Administrative expenses are the direct expenses associated with the overall management and administration of the institution and are defined here as total administrative expenses relative to total expenses. Finally, uncompensated care is equal to the sum of bad debt and charity care and is scaled by gross revenue. ${ }^{8}$ Since excess income margin already accounts for administrative expenses and uncompensated care, the latter two variables capture any additional weight that the hospital places on these two measures. All of the performance variables are scaled to control for the size of the hospital as well as to adjust for the time between reports, which varies across the hospitals in the sample.

\footnotetext{
${ }^{7}$ There are a number of accounting-based performance measures we potentially could have used. We focus on excess income margin rather than operating income since it captures all sources of income, including that from the pharmacy, gift shops, home health services, hotel services for outpatients or families, investments, etc. For the purposes of performance evaluation, all sources of income are relevant, so we use a measure that captures all of them.

${ }^{8}$ Note that in situations where charity care is missing, the hospital likely did not differentiate between charity care and bad debt but reported them together as bad debt.
} 
We choose these three variables because we expect hospital types to value them differentially. For example, district hospitals are potentially more interested in excess income margin than other nonprofits since changes in income will affect the level of tax support needed. Administrative expenses are likely to be viewed differently by different types of hospitals; some boards probably consider incremental administrative expenditures as waste, while others may consider them an investment in better management. Uncompensated care and its components, charity care and bad debt expense, are also potentially valued differently. All nonprofit hospitals are likely to include charity care as part of their organizational mission; however, hospitals with limited income may find it necessary to curtail charity care, when possible. In addition, district hospitals may be reticent to provide charity care when taxes must be raised to support it.

\section{Empirical Results}

\subsection{The Determinants of Board Changes}

At any point in time, board membership is the result of a sequence of incremental changes, each of which was a function of the environment at the time of the change. The first part of our empirical work examines these changes and the factors that are associated with them.

A difficult issue is how one measures changes in the structure of the board. A logical starting-point would be to focus on observable changes in board composition, in terms of the percentages of insiders, outsiders, and other types. However, the nature of our data precludes a focus on changes in composition. Hospitals appear to have compositions that are set by tradition and therefore tend to be constant over time (recall the Carondelet hospital and related discussion in Section 3). Accordingly, to investigate the factors that lead to board changes, we use the level of turnover in the board (regardless of director type) as our measure. Using this measure is consistent with the notion that hospitals change the level of board independence by choosing new directors from the same category but with different levels of ability or willingness 
to question the administration's policies. That is, a successful administration could bargain for a business person friendlier to its position when filling a vacancy in a board seat "reserved" for local business people. Conversely, a less successful administration might have to take a less favorably disposed business person for that seat. ${ }^{9}$

We estimate a model that predicts board turnover as a function of the following variables: an indicator (0-1)-variable to control for changes in ownership, an indicator variable for whether the hospital is a member of a hospital system, the value of the excess income margin (total income scaled by revenue) in the previous year, excess income margin in the previous year times the indicator variable for membership in a hospital system, the value of the ratio of administrative expenses to operating expenses in the previous year, the value of charity care and bad debt expense (scaled by revenue) in the previous year, dummy variables for the years, and the percentages of insiders and outsiders already on the board in the previous year. ${ }^{10}$ New ownership is included because it is highly likely that director turnover occurs at the time of an ownership change but is unrelated to factors valued by the board. Membership in a system is included because the performance of these hospitals is likely to be affected by their relationship with other hospitals in the systems. That is, they may be able to take advantage of economies of scale in purchasing, they may possess better information systems, and other factors. CEO turnover in system hospitals could also be affected because an individual CEO's performance is more visible within the system, because idiosyncratic behavior is more readily identified by comparison with performance at other hospitals in the system. In addition, CEOs in

\footnotetext{
${ }^{9}$ Admittedly, this approach is subject to an alternative interpretation: Directors turn over voluntarily in response to the same factors we use in our empirical work. To test for that possibility, we have estimated equations similar to those presented in Table 4 using various direct measures of change in board composition such as change in the percentage of insiders or outsiders as the dependent variable. These equations have very little explanatory power.

${ }^{10}$ We include lagged percentages of various board categories to distinguish hospital type preference for certain occupational categories from the turnover variation due to different opportunity costs of time among occupational categories.
} 
system hospitals can also be "fired" upward; that is, promoted within the system. ${ }^{11}$ We expect board turnover to be negatively related to lagged excess income margin and positively related to administrative expenses. For the reasons discussed above, we expect these relationships to be particularly strong in for-profit and district hospitals.

Uncompensated care captures two performance variables with potentially conflicting effects - charity care and bad debt. Typically, organizations dislike bad debt; however, different types of organizations potentially place different weights on charity care. For-profit hospitals are likely to treat it as equivalent to bad debt, while nonprofit hospitals, government hospitals, and religious hospitals are likely to consider charity care part of their mission. Therefore, bad debt and charity care could have potentially opposite effects on CEO and board turnover. Variation in emphasis on charity care across hospital types potentially leads to varying signs for uncompensated care. In particular, we expect for-profit hospitals to consider high levels of uncompensated care as being at odds with its objectives. We also expect that teaching, government, and nonprofit hospitals are ambivalent toward uncompensated care because of the charity-care effect.

We measure board turnover as:

(\# new directors at $\mathrm{t})+($ \# directors that left the board between $\mathrm{t}$ and $\mathrm{t}-1)$ 2 * (\# board size at $\mathrm{t}-1)$

This measure has an intuitive interpretation: if two directors leave a board of ten and are replaced by two new directors, turnover will be equal to 20 percent; if there are no additions and no departures, turnover is zero. Although this measure is bounded below by zero, turnover greater than 100 percent is possible. ${ }^{12}$

\footnotetext{
${ }^{11}$ We estimated models with all performance variables interacted with system dummies, but no significant coefficients were obtained for either administrative expense or charity care, so we dropped these interaction variables from our final analyses.

${ }^{12}$ Turnover greater than $100 \%$ will occur, for example, if eight directors in a board of ten leave, and 14 are added to the board (resulting in turnover of $(8+14) /(2 * 10)=110 \%)$.
} 
Table 4 contains estimates of the determinants of turnover. The first column presents the results for all organization types except district hospitals. Since hospital district board members are elected for specific periods of tenure, turnover is unlikely to be related to performance in the current period. This equation indicates that in the overall sample, excess income and uncompensated care are negatively related to board turnover. In this model, we interact the system dummy with excess income margin. ${ }^{13}$ There is no significant difference between system hospitals and others. These findings are consistent with the view that board turnover occurs when a hospital is not fulfilling its objective, since regardless of type, hospitals invariably prefer high accounting income.

We estimate this equation separately by hospital type in the remaining columns of Table 4. The coefficient on excess income is negative for five of the six hospital types, and is significant at the one-percent level for district hospitals and at the ten-percent level for the forprofits. The coefficient for district hospitals is significantly different from the corresponding coefficients for profit, government, and teaching hospitals. The highly significant negative coefficient on district hospital excess income suggests that when the hospital is performing poorly, district hospital directors may be forced to hold elections for tax increases and are then less likely be re-elected to the board when their term expires.

Surprisingly, administrative expenses for religious and government hospitals have significantly negative coefficients. That is, lowering administrative expenditures, presumably a "good" event, increases board turnover. One potential explanation for this finding is that in the mid-80s (after the change in Medicare reimbursement) and again in the early 90 s, occupancy levels dropped as length of stay dropped in the hospital industry (Prospective Payment Assessment Commission, 1994). Hospitals responded by cutting back on personnel, and it is

\footnotetext{
${ }^{13}$ We also ran a model with uncompensated care and administrative expenses interacted with system dummies, but there were no significant coefficients, so we present the results for the model with the interaction between excess income margin and the system dummy.
} 
plausible that inefficient hospitals sustained greater cutbacks in administrative expenses and turned over more board members at the same time. As a sensitivity test, we removed hospitals that exited during the period, and reestimated the equation. The coefficient on religious hospitals loses significance, suggesting that this result is at least partially driven by the exiting hospitals.

Although the coefficient on uncompensated care for the entire sample is negative increased uncompensated care actually lowers board turnover — this effect is significant only for government and teaching hospitals. A consistent explanation for this finding is that government and teaching hospitals value uncompensated care (presumably the charity-care component), and that it is these two hospital types that are driving the overall sample coefficient. Consistent with this explanation, Eldenburg and Vines (2000) find that, for many hospitals, charity care is a small percentage of uncompensated care. It is, however, a large part of uncompensated care for teaching and government hospitals, which do the bulk of charity care in a community.

To better test our model specification, we separate the excess income measure into its positive and negative components, thereby allowing us to treat gains and losses asymmetrically. When we estimate this equation (not reported), we obtain a signficant negative coefficient on "negative excess income" and an insignicant coefficent on "positive excess income" in the pooled regression This finding indicates that bad performance is the more important determinant of the significant negative coefficient on excess income in the equations reported in Table 4.

\subsection{Analysis of CEO turnover}

As a framework for understanding CEO turnover in hospitals, suppose that boards evaluate CEOs' abilities on multiple dimensions. Each dimension has some value to the board, so the overall value of the CEO is a weighted sum of her abilities. CEOs whose sums fall below some threshold lose their jobs. We, of course, cannot observe these scores, nor do we know 
the corresponding weights attached to them. We can, however, observe certain variables that are correlated with abilities. This allows us to "estimate" the composite score as a weighted sum of the observable variables, where the weights are estimated treating CEO turnover as the dependent variable.

Specifically, we analyze the determinants of CEO turnover for hospitals of various organizational forms. Our approach follows a large literature that has examined the factors leading to CEO turnover (see, e.g., Warner et. al, 1988; Weisbach, 1988; Barro and Barro, 1990; Gibbons and Murphy, 1990; Jensen and Murphy, 1990; Kaplan, 1994; and Blackwell et. al, 1994). The underlying assumption of our analysis here — in fact, of this entire literature — is that noise in the turnover relationship is uncorrelated with the independent variables. ${ }^{14}$ Given this underlying assumption, any association we measure reflects a relation between involuntary turnover and the independent variables in our equation. ${ }^{15}$

We use a logit model to estimate the probability of CEO turnover conditional on hospital characteristics and performance. As in the model of Table 4, we include indicator variables for new ownership and system membership, the lagged value of excess income margin, an interaction term for systems and excess income margin, the lagged value of the ratio of administrative expenses to operating expenses, the lagged value of charity care and bad debt expense (scaled by revenue), and dummy variables for each year.

Table 5 presents estimates of this equation for all hospital types pooled and for each type individually. These results suggest that CEO turnover is higher when excess income is lower, and when administrative expenses are higher; the coefficients in the pooled equation on excess income, and administrative costs are statistically significant at all conventional levels.

\footnotetext{
${ }^{14}$ To be more specific, any turnover other than dismissal is due to factors uncorrelated with performance measures (e.g., death) or is done in anticipation of dismissal (i.e., the "you can't fire me, I quit" scenario).

${ }^{15}$ Another possibility is that higher quality CEOs are more likely to leave, since they have better outside opportunities. To the extent that voluntary departures are positively associated with turnover, the coefficient on performance will be biased downwards in absolute value.
} 
CEO turnover is also higher in systems hospitals. The effects for excess income margin tend to mirror those for board turnover in that poor performance leads to higher turnover.

There is cross-sectional variation across hospital types in terms of the factors predicting CEO turnover. The coefficient on excess income is negative and significant for all hospitals except religious and government non-system hospitals. The incremental effect of system hospitals for government and district hospitals suggests that they behave differently from nonsystem hospitals. When we ran the regression without the interaction term, the net effects of the coefficients on excess income margin were negative for other nonprofit $(p<.001)$, for-profit $(p<.001)$, and district hospitals $(p<.10)$. In religious, government, and teaching hospitals the coefficients on excess income margin were insignificant. Overall, the results suggest that negative income increases the likelihood of CEO turnover.

Higher administrative expenses increase the likelihood of CEO turnover in all types of hospitals. However, the coefficients vary in both size and statistical significance - the coefficients are significant in for-profit, district, and teaching hospitals. These positive coefficients suggest that for-profit, district and teaching hospital boards are most prone to view administrative expenses as waste, and to discipline managers for excessive expenses.

The quality of our data for uncompensated care limits the extent to which they can predict management turnover. , We do, however, find a marginally significant positive coefficient for religious and district hospitals, suggesting that an increase in uncompensated care is associated with increased CEO turnover in these hospitals. Our conversations with the CEO of a local Catholic hospital suggested that she made trade-offs between the operating margin and levels of charity care. Accordingly, when operating margin is low, pressure may be exerted on CEOs to keep charity care levels low. When we re-ran the regression using a balanced panel of hospitals with complete data over the time period (no exiting hospitals), the coefficient on uncompensated care in religious hospitals loses significance $(p=0.71)$. Hence the significantly 
negative coefficient in Table 5 results from exiting religious hospitals. The coefficient for district hospitals remains significantly positive $(p<0.07) .^{16}$

Overall, the results on CEO turnover are consistent with the joint hypotheses that hospital CEOs are more likely to turn over when the hospital does not achieve its objectives, and that these objectives vary across hospital types. Accounting performance, uncompensated care, and administrative expenses appear to be correlated with factors entering hospital objective functions. Consistent with the results of Brickley and Van Horn (2000), our findings suggest that the differences between for-profit hospitals and nonprofit hospitals are not as stark as one might imagine. Rather, they suggest that the most important differences in hospital objectives are between different types of nonprofit hospitals.

\subsection{Further analysis of uncompensated care}

As noted earlier, the data for charity care and bad debt separately is available in about half of hospital-years. However, this availability varies by organizational type over time (see Table 2). Hospitals that used a federal program (The Hill-Burton program) to insure debt for capital expenditures (which lowered their interest rates) were required to maintain charity care at contracted-upon levels and to report charity care to the state on an annual basis. Data for these hospitals are relatively complete. Accounting regulations changed in 1990 and all hospitals were required to report charity care and bad debt expense separately to meet Generally Accepted Accounting Principles for hospitals. The most complete charity data after 1990 is provided by religious, teaching and other nonprofit hospitals. ${ }^{17}$

We re-estimate CEO turnover equations similar to those in Table 5 using religious, teaching, and other nonprofit hospitals, using charity care and bad debt when it is available, and

\footnotetext{
${ }^{16}$ To the extent that uncompensated care reflects bad debt, all hospitals have incentive to keep bad debt levels low.

${ }^{17}$ Only 1.6 percent of religious hospital-years have missing charity data after 1990 . The percentages are 3.5 and 8.7 for teaching and nonprofit respectively. Requiring data on charity care causes us to lose 3 , 11 and 51 hospital-years in religious, teaching and nonprofit hospital samples respectively.
} 
uncompensated care otherwise. The coefficients on charity care are consistently negative and the coefficients on bad debt are consistently positive. Only the coefficient on bad debt in religious hospitals is significant, however. When exiting hospitals are removed from the regression, religious hospitals exhibit a negative $(p<0.10)$ coefficient for charity care and a positive $(p<0.10)$ coefficient for bad debt. For-profit hospitals have positive (but insignificant) coefficients on both charity care and bad debt. These results provide some evidence that charity care is valued positively and bad debt is valued negatively by the nonprofit hospitals. A Wald test of the hypothesis that the coefficients on bad debt and charity care in religious hospitals are the same rejects at the five-percent level, indicating that religious hospitals value these two components of uncompensated care differently.

We also examine the possibility that hospitals respond differently to uncompensated care depending on their excess income margins. Our hypothesis is that hospitals will place less emphasis on uncompensated care when financial performance is poor relative to when they are performing well. We separate uncompensated care into two variables: uncompensated care when excess income margin is nonnegative (zero otherwise), and uncompensated care when excess income margin is negative (zero otherwise). The coefficient for uncompensated care under loss conditions for religious and district hospitals is significantly positive ( $p$-value $<0.05)$.

Because district boards are elected and taxes may be raised if the hospital is financially constrained, it is plausible that monitoring increases when there are losses. Government hospitals exhibit a positive coefficient $(p<0.10)$ on uncompensated care when excess income margin is nonnegative. The sample of government hospitals is small and this result may reflect hiring away of competent CEOs who are able to increase margin and uncompensated care simultaneously.

\subsection{Hospitals that Exit the Sample Early}

As mentioned earlier, the panel used in this study is not balanced. Out of 488 hospitals, only 381 appear for the entire length of the panel. Sixteen hospitals begin operations during the 
period we are studying. However, the number of early exits from our panel (110) raises the possibility of selection bias. The early exits can be broken into three separate categories: hospitals (62) that go out of business, ${ }^{18}$ hospitals (32) that change their primary service to longterm care i.e., nursing homes, and hospitals (16) that exit the panel through merger with another facility.

Table 6 provides statistics on the hospitals that exit the sample early. These hospitals differ in important ways from other hospitals. In particular, they have worse average performance, higher CEO and board turnovers, higher administrative expenses, and more numerous ownership changes.

To investigate the effects of early exit hospitals, we run the board turnover and CEO turnover regressions from Tables 4 and 5 including only those hospitals that were in the sample for the entire period. The results from these regressions are very similar to those reported earlier; the signs on the coefficients and significance levels do not change in a noticeable way. ${ }^{19}$

\subsection{Other Sensitivity Analysis}

An alternative measure for teaching hospitals is to classify only members of the Council of Teaching Hospitals (COTH) as teaching hospitals. To test the robustness of a broader definition (all hospitals with residency programs resulting in 901 complete CEO observations), we re-ran regression using only COTH hospitals. These results indicated that the hospitals in our teaching sub-sample behaved similarly to the COTH hospitals and were less similar to hospitals in their organizational type (religious, nonprofit, government or district). We conclude that the broader measure of teaching hospitals is more appropriate for this study.

\footnotetext{
${ }^{18}$ In five cases the facility opens several years later under new ownership.

${ }^{19}$ The only exception is uncompensated care in the 'all types' pooled regression where the coefficient estimated without exit hospitals increases to 1.04 and becomes significant at the $10 \%$ level. In the regression for district hospitals only, the uncompensated care coefficient also increases in both size and significance level.
} 
We included dummy variables for each year to control for economic and technological changes that might affect all hospitals in our sample. We performed sensitivity analysis by splitting the time period into three periods, pre-1984 (when most insurers paid on a cost-plus basis), 1984-1989 (immediately after Medicare's change to flat-fee reimbursement for inpatients), and post-1990 (characterized by high penetration of HMOs). The pooled regression results (not reported) suggest that hospitals were more sensitive to excess income margin prior to 1984 and again after 1990. Since West Coast hospitals have lower average costs than national hospitals, Medicare reimbursement (which incorporated national averages) more than covered costs for California hospitals in the first few years after the reimbursement change in 1983. Hospitals may have geared up for a more difficult reimbursement environment by emphasizing excess income margin, then eased off when the new payment system was favorable, but re-emphasized margin in the 1990s when HMOs penetrated the market. The results for administrative expenses are consistent across time, and uncompensated care was given positive weight prior to 1990 , after which it was viewed negatively. ${ }^{20}$

\section{Conclusions}

This paper studies the governance of a sample of California hospitals. Hospitals provide a natural place to study governance because they are relatively similar to one another in the types of services they provide, but occur in a number of different organizational forms. Hospitals of different organizational forms are likely to have different objective functions to maximize. The empirical implication of these different objective functions is that the relation between the governance structures of hospitals of different organizational forms and factors associated with the objective functions will vary systematically across types of hospitals.

\footnotetext{
${ }^{20}$ In 1990 the AICPA required hospitals to report bad debt expense and charity care separately, rather than aggregated as uncompensated care. This new reporting practice provides stronger incentives to reduce bad debt since the dollar amounts are now subject to public scrutiny.
} 
We document a number of empirical relations consistent with this view. First, we find that the composition of the board of directors varies systematically across ownership types. These differences in board composition and size are quite substantial, and appear to be stable over a period of time with major changes in the industry. Second, we estimate the factors that affect the turnover in the board of directors. We find that poor performance and low levels of uncompensated care increase board turnover. The sensitivity of board turnover to these factors varies by organizational form. Finally, we consider the determinants of CEO turnover in our sample of hospitals. We find that poor performance, high administrative costs, and high uncompensated care lead to higher CEO turnover. Again, different hospital types appear to place different weights on each of these variables. These results are largely consistent with the view that different types of hospitals have different objective functions, and hence use different combinations of these variables in their performance evaluation system.

In addition to their implications for governance, our results also add to the healthcare literature. We confirm the findings of other researchers that performance measures valued by nonprofit hospitals are similar to performance measures valued by for-profits. We also find that charity and uncompensated care are not valued similarly by hospital management, as often is assumed by healthcare researchers.

Overall, this paper documents that the structure of ownership has a large impact on hospital governance. Governance in different organizational forms appears to function differently from one another. These findings raise a number of interesting questions: What process is used and what factors are considered when a nonprofit organization chooses an objective function? What is the "market" equilibrium regarding nonprofits, in terms of which organizations survive, and what distribution of objectives exist in equilibrium? What is it about organizations of different ownership types and their presumed differences in objectives that lead them to adopt different governance structures? To what extent should we expect to see convergent or divergent evolution in the governance structures? What omitted factors differ 
across hospital types that could potentially provide alternative explanations for our results? Are there any other implications of different objective functions one might reasonably expect to observe in the data? A deeper understanding of these issues certainly warrants further research. 


\section{References}

Alexander, Morrisey, and S. Shortell (1986) "Physician Participation in the Administration and Governance of System and Freestanding Hospitals: A Comparison by Type of Ownership." (Bradford Gray ed.) For-profit Enterprise in Health Care. Washington, D.C.: National Academy Press, 1986, pages 402-21

Baker, M. and P. Gompers (2000) "The Determinants of Board Structure and Function in Entrepreneurial Firms,” Working Paper, Harvard Business School.

Barro, J. and R. Barro (1990) "Pay, Performance, and Turnover of Bank CEOs," Journal of Labor Economics, 8, 448-481.

Beekun, R., Y. Stedham, and G. Young (1998) "Board Characteristics, Managerial controls and Corporate Strategy: A Study of U.S. Hospitals," Journal of Management, 24:1, pages 3-19.

Bhagat, S. and B. Black (2000) "Board Independence and Long-Term Firm Performance, “ Working Paper, University of Colorado.

Blackwell, D., J. Brickley, and M. Weisbach (1994) "Accounting Information and Internal Performance Evaluation: Evidence from Texas Banks," Journal of Accounting and Economics, 17, 331-358.

Boeker and Goodstein (1991) "Organizational Performance and Adaptation: Effects of Environment and Performance on Changes in Board Composition." Academy of Management Journal, 34(4), 805-826.

Brickley, J., J. Coles, and R. Terry (1994) "Outside Directors and the Adoption of Poison Pills," Journal of Financial Economics, 35, 371-390.

Brickley, J. and C. James (1987) "The Takeover Market, Corporate Board Composition, and Ownership Structure: The Case of Banking," Journal of Law and Economics, 30, 161-180.

Brickley, J. and R. L. Van Horn (2000) "Incentives in Nonprofit Organizations: Evidence from Hospitals," Working Paper, University of Rochester.

Buczko, W. (1994) "Factors Affecting Charity Care and Bad Debt Charges in Washington Hospitals," Hospital and Health Services Administration, 39(2), 179-191.

Demsetz, H. and K. Lehn (1985) "The Structure of Corporate Ownership: Causes and Consequences," Journal of Political Economy, 93, 1155-1177.

Denis, D. and A. Sarin (1999) "Ownership and Board Structures in Publicly-Traded Corporations," Journal of Financial Economics, 52, 187-224.

Eldenburg, L. and C. Vines (2000) "Nonprofit Classification Decisions in Response to a Change in Accounting Rules," Working Paper, University of Arizona.

Gibbons, R. and K. Murphy (1990) "Relative Performance Evaluation for Chief Executive Officers," Industrial and Labor Relations Review, 43, pp. 30-51.

Government Accounting Office (GAO), 1990, Report to the Chairman, Select Committee on Aging, House of Representatives: Non-Profit Hospitals - Better Standards Needed for Tax Exemption, GAO/HRD-90-84, May, Washington D.C.

Hermalin, B. and N. Wallace (1994) "The Determinants of Efficiency and Solvency in Savings and Loans," RAND Journal of Economics, 25(3), Autumn 1994, pp. 361-381.

Hermalin, B. and M. Weisbach (1988) "The Determinants of Board Composition," RAND Journal of Economics, 19, pp. 589-606. 
Hermalin, B. and M. Weisbach (1991) "The Effects of Board Composition and Direct Incentives on Firm Performance," Financial Management, 20, pp. 101-112.

Hermalin, B. and M. Weisbach (1998) "Endogenously Chosen Boards of Directors and their Monitoring of the CEO," American Economic Review, 88, pp. 96-118.

Hermalin, B. and M. Weisbach (2000) "Boards of Directors as an Endogenously-Determined Institution: A Survey of the Economic Literature," Economic Policy Review, forthcoming.

Jensen, M. and K. Murphy (1990) "Performance Pay and Top-Management Incentives," Journal of Political Economy, 98, pp. 225-264.

Judge, W. and Zeithaml, C. (1992) "Institutional and Strategic Choice Perspectives on Board Involvement in the Strategic Decision Process," Academy of Management Journal, 35(4), 766-794.

Kaplan, S. (1994) "Top Executive Rewards and Firm Performance: A Comparison of Japan and the U.S.," Journal of Political Economy, 102, 510-546.

Kroszner, R. and P. Strahan (2000) "Bankers on Boards: Monitoring, Conflicts of Interest, and Lender Liability," Journal of Financial Economics, forthcoming.

Mace (1986) Directors: Myth and Reality, Harvard Business School Press: Boston.

Morck, R., A. Sheifer, and R. Vishny (1988) "Management Ownership and Market Valuation," Journal of Financial Economics, 20, 293-315.

Prospective Payment Assessment Commission (ProPAC), June 1994, Medicare and the American health care system. Report to Congress (Commerce Clearing House, Chicago, IL).

Shleifer, A. and R. Vishny (1997) "A Survey of Corporate Governance," Journal of Finance, 52, 737-784.

Shivdasani, A. (1993) "Board Composition, Ownership Structure, and Hostile Takeovers," Journal of Accounting and Economics, 16, 167-198.

Shivdasani, A. and D. Yermack (1999) "CEO Involvement in the Selection of New Board Members, " Journal of Finance, 54, 1829-1854.

Tufano, P. and M. Sevick, (1997) "Board Structure and Fee-Setting in the U.S. Mutual Fund Industry," Journal of Financial Economics 46, 321-356.

Warner, J., R. Watts, and K. Wruck (1988) "Stock Prices and Top-Management Changes," Journal of Financial Economics, 20.

Weisbach, M. (1988), "Outside Directors and CEO Turnover," Journal of Financial Economics, 20, 431-460.

Yermack, D. (1996) "Higher Valuation of Companies with a Small Board of Directors," Journal of Financial Economics, 40, 185-212.

Young, G. (1996/97) "Insider Representation on the Governing Boards of Nonprofit Hospitals: Trends and Implications for Charitable Care," Inquiry 33: 352-362.

Young, G., Y. Stedham, and R. Beekun (2000) "Boards of Directors and the Adoption of a CEO Performance Evaluation Process: Agency and Institutional Theory Perspectives," Journal of Management Studies, 37:2, pages 277-295. 


\section{Table 1: Organizational Changes and System Affiliation across Hospital Types}

This table provides statistics on organizational changes across hospitals. Our sample consists of 486 California acute care hospitals between 1980-1996.

\begin{tabular}{|l||c|c|c|c|c|c|c||}
\hline Variable & All types & Religious & Nonprofit & Profit & $\begin{array}{c}\text { Govern- } \\
\text { ment }\end{array}$ & District & Teaching \\
\hline \hline \# of hospital-years & 6434 & 581 & 1873 & 1959 & 291 & 806 & 924 \\
\hline \# of ownership changes & 157 & 9 & 35 & 96 & 4 & 6 & 7 \\
\hline $\begin{array}{l}\text { \# of hospitals that switch } \\
\text { to this type from another }\end{array}$ & 59 & 8 & 27 & 19 & 2 & 3 & 0 \\
\hline $\begin{array}{l}\text { \# of hospitals that switch } \\
\text { from this type to another }\end{array}$ & 59 & 2 & 23 & 18 & 8 & 8 & 0 \\
\hline \# of late entries & 19 & 2 & 8 & 6 & 0 & 2 & 1 \\
\hline \# going out of business & 62 & 6 & 17 & 29 & 6 & 4 & 0 \\
\hline $\begin{array}{l}\text { \# exiting the panel } \\
\text { through merger }\end{array}$ & 16 & 3 & 4 & 7 & 0 & 0 & 2 \\
\hline $\begin{array}{l}\text { \# exiting to long-term } \\
\text { nursing care facilities }\end{array}$ & 31 & 3 & 6 & 18 & 1 & 3 & 0 \\
\hline $\begin{array}{l}\text { \# of hospital-years with } \\
\text { system affiliation }\end{array}$ & 3047 & 462 & 563 & 1357 & 101 & 109 & 455 \\
\hline
\end{tabular}




\section{Table 2: Statistics on CEO Turnover and Performance Variables}

This table presents the mean and median values of a number of variables across hospital types. Our sample consists of 486 California acute care hospitals between 1980-1996. Mean values are not formatted, standard deviations are in parentheses and median values are in italics. CEO Turnover is 1 in years when turnover occurs and 0 otherwise. Excess income margin is the ratio of gross operating and non-operating income to gross revenue. Administrative expenses are total administrative expenses relative to total expenses. Uncompensated care is equal to the sum of bad debt and charity care, and is scaled by total patient revenue. Bad debt and charity care are scaled by gross revenue.

\begin{tabular}{|c|c|c|c|c|c|c|c|}
\hline Variable & All types & Religious & Nonprofit & Profit & $\begin{array}{c}\text { Govern- } \\
\text { ment }\end{array}$ & District & Teaching \\
\hline $\begin{array}{l}\text { Number of complete } \\
\text { observations }^{a}\end{array}$ & 6162 & 551 & 1794 & 1847 & 267 & 789 & 914 \\
\hline CEO turnover & $\begin{array}{c}0.254 \\
(0.435) \\
0\end{array}$ & $\begin{array}{c}0.172 \\
(0.378) \\
0\end{array}$ & $\begin{array}{c}0.203 \\
(0.404) \\
0\end{array}$ & $\begin{array}{c}0.346 \\
(0.477) \\
0\end{array}$ & $\begin{array}{c}0.360 \\
(0.481) \\
0\end{array}$ & $\begin{array}{c}0.245 \\
(0.432) \\
0\end{array}$ & $\begin{array}{c}0.195 \\
(0.394) \\
0\end{array}$ \\
\hline Excess income margin & $\begin{array}{c}0.021 \\
(0.079) \\
0.026\end{array}$ & $\begin{array}{c}0.021 \\
(0.087) \\
0.032\end{array}$ & $\begin{array}{c}0.211 \\
(0.069) \\
0.025\end{array}$ & $\begin{array}{c}0.022 \\
(0.105) \\
0.031\end{array}$ & $\begin{array}{c}-0.006 \\
(0.104) \\
0.000\end{array}$ & $\begin{array}{c}0.017 \\
(0.075) \\
0.024\end{array}$ & $\begin{array}{c}0.033 \\
(0.056) \\
0.029\end{array}$ \\
\hline $\begin{array}{l}\text { Administrative } \\
\text { expenses }\end{array}$ & $\begin{array}{c}0.049 \\
(0.031) \\
0.041\end{array}$ & $\begin{array}{c}0.049 \\
(0.023) \\
0.046\end{array}$ & $\begin{array}{c}0.041 \\
(0.022) \\
0.036\end{array}$ & $\begin{array}{c}0.068 \\
(0.041) \\
0.063\end{array}$ & $\begin{array}{c}0.043 \\
(0.026) \\
0.033\end{array}$ & $\begin{array}{c}0.040 \\
(0.020) \\
0.036\end{array}$ & $\begin{array}{c}0.036 \\
(0.020) \\
0.033\end{array}$ \\
\hline Uncompensated care & $\begin{array}{c}0.046 \\
(0.059) \\
0.030\end{array}$ & $\begin{array}{c}0.032 \\
(0.015) \\
0.029\end{array}$ & $\begin{array}{c}0.034 \\
(0.024) \\
0.030\end{array}$ & $\begin{array}{c}0.032 \\
(0.031) \\
0.025\end{array}$ & $\begin{array}{c}0.132 \\
(0.115) \\
0.092\end{array}$ & $\begin{array}{c}0.041 \\
(0.028) \\
0.035\end{array}$ & $\begin{array}{c}0.084 \\
(0.106) \\
0.037\end{array}$ \\
\hline Bad debt & $\begin{array}{c}0.030 \\
(0.025) \\
0.024\end{array}$ & $\begin{array}{c}0.023 \\
(0.012) \\
0.021\end{array}$ & $\begin{array}{c}0.026 \\
(0.015) \\
0.022\end{array}$ & $\begin{array}{c}0.025 \\
(0.019) \\
0.020\end{array}$ & $\begin{array}{c}0.054 \\
(0.041) \\
0.048\end{array}$ & $\begin{array}{c}0.031 \\
(0.017) \\
0.028\end{array}$ & $\begin{array}{c}0.036 \\
(0.037) \\
0.025\end{array}$ \\
\hline Charity care & $\begin{array}{c}0.025 \\
(0.062) \\
0.007\end{array}$ & $\begin{array}{c}0.009 \\
(0.009) \\
0.007\end{array}$ & $\begin{array}{c}0.010 \\
(0.013) \\
0.006\end{array}$ & $\begin{array}{c}0.007 \\
(0.011) \\
0.002\end{array}$ & $\begin{array}{c}0.102 \\
(0.115) \\
0.067\end{array}$ & $\begin{array}{c}0.009 \\
(0.010) \\
0.006\end{array}$ & $\begin{array}{c}0.056 \\
(0.010) \\
0.011\end{array}$ \\
\hline $\begin{array}{l}\text { Number of } \\
\text { observations with } \\
\text { complete charity care }\end{array}$ & 3320 & 477 & 1176 & 356 & 186 & 357 & 768 \\
\hline
\end{tabular}

${ }^{a}$ Only excess income margin, administrative expenses and uncompensated care are considered in this statistic. 
Table 3: Board of Directors of Different Types of Hospitals

This table presents statistics on the board of directors of hospitals of different types. Our sample consists of 486 California acute care hospitals between 1980-1996. Standard deviations are in parenthesis.

Board turnover is defined as:

\section{(\# new directors at $\mathrm{t})+(\#$ directors that left the board between $\mathrm{t}$ and $\mathrm{t}-1)$ $2^{*}$ (\# board size at $\left.\mathrm{t}-1\right)$}

We classify CEOs and hospital administrative personnel as insiders. NON-BUSINESS Outsiders include educators, community members, homemakers, clergy. Clergy board members in a religious hospital are considered as insiders.

\begin{tabular}{|c|c|c|c|c|c|c|c|c|}
\hline \multicolumn{2}{|c|}{ Variable } & All types & Religious & Nonprofit & Profit & $\begin{array}{c}\text { Govern- } \\
\text { ment } \\
\end{array}$ & District & Teaching \\
\hline \multicolumn{2}{|c|}{$\begin{array}{l}\text { Number of complete } \\
\text { observations }\end{array}$} & 5910 & 545 & 1757 & 1717 & 257 & 783 & 851 \\
\hline \multicolumn{2}{|c|}{ Board turnover } & $\begin{array}{c}0.201 \\
(0.234) \\
0.147\end{array}$ & $\begin{array}{c}0.210 \\
(0.177) \\
0.180\end{array}$ & $\begin{array}{c}0.174 \\
(0.176) \\
0.133\end{array}$ & $\begin{array}{c}0.256 \\
(0.306) \\
0.167\end{array}$ & $\begin{array}{c}0.181 \\
(0.268) \\
0.1\end{array}$ & $\begin{array}{c}0.168 \\
(0.207) \\
0.1\end{array}$ & $\begin{array}{c}0.175 \\
(0.193) \\
0.143\end{array}$ \\
\hline \multicolumn{2}{|c|}{ Board size } & $\begin{array}{c}11.15 \\
(5.79) \\
10\end{array}$ & $\begin{array}{c}13.47 \\
(4.22) \\
14\end{array}$ & $\begin{array}{c}13.61 \\
(5.10) \\
13\end{array}$ & $\begin{array}{c}9.81 \\
(4.65) \\
9\end{array}$ & $\begin{array}{c}5.91 \\
(2.06) \\
5\end{array}$ & $\begin{array}{c}5.29 \\
(1.25) \\
5\end{array}$ & $\begin{array}{c}14.24 \\
(7.22) \\
15\end{array}$ \\
\hline \multicolumn{2}{|c|}{ Fraction Insiders } & $\begin{array}{c}0.101 \\
(0.167) \\
0\end{array}$ & $\begin{array}{c}0.356 \\
(0.208) \\
0.333\end{array}$ & $\begin{array}{c}0.055 \\
(0.079) \\
0\end{array}$ & $\begin{array}{c}0.136 \\
(0.196) \\
0.077\end{array}$ & $\begin{array}{c}0.023 \\
(0.077) \\
0\end{array}$ & $\begin{array}{c}0.014 \\
(0.054) \\
0\end{array}$ & $\begin{array}{c}0.062 \\
(0.101) \\
0\end{array}$ \\
\hline \multicolumn{2}{|c|}{$\begin{array}{l}\text { Fraction medical } \\
\text { personnel }\end{array}$} & $\begin{array}{c}0.275 \\
(0.235) \\
0.231\end{array}$ & $\begin{array}{c}0.196 \\
(0.112) \\
0.2\end{array}$ & $\begin{array}{c}0.259 \\
(0.148) \\
0.25\end{array}$ & $\begin{array}{c}0.421 \\
(0.302) \\
0.4\end{array}$ & $\begin{array}{c}0.051 \\
(0.111) \\
0\end{array}$ & $\begin{array}{c}0.243 \\
(0.220) \\
0.2\end{array}$ & $\begin{array}{c}0.160 \\
(0.146) \\
0.158\end{array}$ \\
\hline \multirow{5}{*}{ 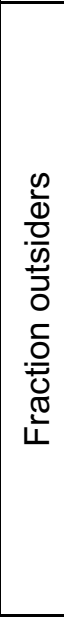 } & All outsiders & $\begin{array}{c}0.555 \\
(0.284) \\
0.6\end{array}$ & $\begin{array}{c}0.396 \\
(0.179) \\
0.4\end{array}$ & $\begin{array}{c}0.642 \\
(0.191) \\
0.667\end{array}$ & $\begin{array}{c}0.323 \\
(0.245) \\
0.308\end{array}$ & $\begin{array}{c}0.860 \\
(0.267) \\
1\end{array}$ & $\begin{array}{c}0.713 \\
(0.224) \\
0.8\end{array}$ & $\begin{array}{c}0.705 \\
(0.247) \\
0.722\end{array}$ \\
\hline & $\begin{array}{l}\text { Fraction Outside } \\
\text { Executives }\end{array}$ & $\begin{array}{c}0.065 \\
(0.142) \\
0\end{array}$ & $\begin{array}{c}0.069 \\
(0.122) \\
0\end{array}$ & $\begin{array}{c}0.052 \\
(0.115) \\
0\end{array}$ & $\begin{array}{c}0.108 \\
(0.192) \\
0\end{array}$ & $\begin{array}{c}0.007 \\
(0.047) \\
0\end{array}$ & $\begin{array}{c}0.015 \\
(0.062) \\
0\end{array}$ & $\begin{array}{c}0.069 \\
(0.133) \\
0\end{array}$ \\
\hline & $\begin{array}{l}\text { Fraction Other } \\
\text { Businesspeople }\end{array}$ & $\begin{array}{c}0.223 \\
(0.209) \\
0.2\end{array}$ & $\begin{array}{c}0.192 \\
(0.130) \\
0.182\end{array}$ & $\begin{array}{c}0.297 \\
(0.197) \\
0.278\end{array}$ & $\begin{array}{c}0.117 \\
(0.165) \\
0.054\end{array}$ & $\begin{array}{c}0.178 \\
(0.244) \\
0\end{array}$ & $\begin{array}{c}0.370 \\
(0.229) \\
0.4\end{array}$ & $\begin{array}{c}0.188 \\
(0.189) \\
0.154\end{array}$ \\
\hline & $\begin{array}{l}\text { Fraction Non- } \\
\text { Business Outsiders }\end{array}$ & $\begin{array}{c}0.179 \\
(0.245) \\
0.102\end{array}$ & $\begin{array}{c}0.065 \\
(0.080) \\
0.053\end{array}$ & $\begin{array}{c}0.155 \\
(0.144) \\
0.125\end{array}$ & $\begin{array}{c}0.052 \\
(0.090) \\
0\end{array}$ & $\begin{array}{c}0.646 \\
(0.378) \\
0.6\end{array}$ & $\begin{array}{c}0.245 \\
(0.223) \\
0.2\end{array}$ & $\begin{array}{c}0.359 \\
(0.349) \\
0.231\end{array}$ \\
\hline & $\begin{array}{l}\text { Fraction Bankers, } \\
\text { Lawyers \& } \\
\text { Financial Advisors }\end{array}$ & $\begin{array}{c}0.086 \\
(0.103) \\
0.059\end{array}$ & $\begin{array}{c}0.069 \\
(0.070) \\
0.063\end{array}$ & $\begin{array}{c}0.139 \\
(0.100) \\
0.125\end{array}$ & $\begin{array}{c}0.046 \\
(0.081) \\
0\end{array}$ & $\begin{array}{c}0.029 \\
(0.075) \\
0\end{array}$ & $\begin{array}{c}0.084 \\
(0.120) \\
0\end{array}$ & $\begin{array}{c}0.089 \\
(0.107) \\
0.056\end{array}$ \\
\hline \multicolumn{2}{|c|}{$\begin{array}{l}\text { Fraction of Directors } \\
\text { with Unknown } \\
\text { Occupation }\end{array}$} & $\begin{array}{c}0.070 \\
(0.175) \\
0\end{array}$ & $\begin{array}{c}0.050 \\
(0.103) \\
0\end{array}$ & $\begin{array}{c}0.043 \\
(0.120) \\
0\end{array}$ & $\begin{array}{c}0.119 \\
(0.227) \\
0\end{array}$ & $\begin{array}{c}0.065 \\
(0.237) \\
0 \\
\end{array}$ & $\begin{array}{c}0.030 \\
(0.091) \\
0\end{array}$ & $\begin{array}{c}0.073 \\
(0.193) \\
0\end{array}$ \\
\hline
\end{tabular}




\section{Table 4: Estimated Equations Predicting Board Turnover}

This regression presents the results of ordinary least squares regressions, where the dependent variable is board turnover defined as:

$$
\frac{(\# \text { new directors at } \mathrm{t})+(\# \text { directors that left the board between } \mathrm{t} \text { and } \mathrm{t}-1)}{2^{*}(\# \text { board size at } \mathrm{t}-1)}
$$

Our sample consists of 486 California acute care hospitals between 1980-1996. White robust standard errors are in parentheses. Intercepts are not reported (all were positive and significant) and neither are time fixed effects and hospital type dummies in the "all types" regression. System is an indicator variable for system affiliation. Excess income margin is the ratio of gross operating and non-operating income to gross revenue. Administrative expenses are total administrative expenses relative to total expenses. Uncompensated care is the sum of bad debt and charity care scaled by gross revenue. For-profit hospitals are the baseline in the 'all types' regression. Insiders are the omitted category in all

\begin{tabular}{|c|c|c|c|c|c|c|c|}
\hline Variable & $\begin{array}{l}\text { All types } \\
\text { but districts }\end{array}$ & Religious & Nonprofit & Profit & $\begin{array}{l}\text { Govern- } \\
\text { ment }\end{array}$ & District & Teaching \\
\hline New ownership & $\begin{array}{l}0.424^{* * *} \\
(0.046)\end{array}$ & $\begin{array}{l}0.420^{* * *} \\
(0.048)\end{array}$ & $\begin{array}{l}0.408^{* * *} \\
(0.084)\end{array}$ & $\begin{array}{l}0.374^{* * *} \\
(0.060)\end{array}$ & $\begin{array}{l}0.779^{* * *} \\
(0.186)\end{array}$ & $\begin{array}{l}0.615^{* * *} \\
(0.195)\end{array}$ & $\begin{array}{l}0.493^{* * \star} \\
(0.150)\end{array}$ \\
\hline System & $\begin{array}{l}0.029^{* * *} \\
(0.008)\end{array}$ & $\begin{array}{c}0.003 \\
(0.021)\end{array}$ & $\begin{array}{c}0.009 \\
(0.011)\end{array}$ & $\begin{array}{l}0.065^{\star \star \star} \\
(0.016)\end{array}$ & $\begin{array}{l}-0.009 \\
(0.027) \\
\end{array}$ & $\begin{array}{l}0.048^{\star *} \\
(0.021)\end{array}$ & $\begin{array}{c}0.019 \\
(0.017)\end{array}$ \\
\hline Excess income * system & $\begin{array}{c}0.084 \\
(0.090) \\
\end{array}$ & $\begin{array}{l}-0.212 \\
(0.160) \\
\end{array}$ & $\begin{array}{l}-0.048 \\
(0.163) \\
\end{array}$ & $\begin{array}{c}0.196 \\
(0.176) \\
\end{array}$ & $\begin{array}{l}0.872^{\star \star \star} \\
(0.298)\end{array}$ & $\begin{array}{l}-0.126 \\
(0.248) \\
\end{array}$ & $\begin{array}{l}-0.147 \\
(0.225) \\
\end{array}$ \\
\hline Excess income & $\begin{array}{l}-0.165^{\star * \star} \\
(0.066)\end{array}$ & $\begin{array}{l}-0.135 \\
(0.086)\end{array}$ & $\begin{array}{l}-0.116 \\
(0.097) \\
\end{array}$ & $\begin{array}{l}-0.269^{*} \\
(0.152)\end{array}$ & $\begin{array}{l}-0.181 \\
(0.191) \\
\end{array}$ & $\begin{array}{l}-0.394^{* * *} \\
(0.132)\end{array}$ & $\begin{array}{l}0.097 \\
(0.196)\end{array}$ \\
\hline Uncompensated care & $\begin{array}{l}-0.256^{\star \star \star} \\
(0.051)\end{array}$ & $\begin{array}{c}0.171 \\
(0.514) \\
\end{array}$ & $\begin{array}{c}0.338 \\
(0.227) \\
\end{array}$ & $\begin{array}{c}0.072 \\
(0.292) \\
\end{array}$ & $\begin{array}{l}-0.327^{\star \star \star} \\
(0.121) \\
\end{array}$ & $\begin{array}{c}0.107 \\
(0.292) \\
\end{array}$ & $\begin{array}{l}-0.236^{* \star \star} \\
(0.070)\end{array}$ \\
\hline Administrative expenses & $\begin{array}{c}0.130 \\
(0.148) \\
\end{array}$ & $\begin{array}{l}-0.745^{\star *} \\
(0.359)\end{array}$ & $\begin{array}{c}0.346 \\
(0.246)\end{array}$ & $\begin{array}{l}-0.026 \\
(0.215) \\
\end{array}$ & $\begin{array}{l}-0.902^{* * *} \\
(0.497)\end{array}$ & $\begin{array}{c}0.060 \\
(0.365) \\
\end{array}$ & $\begin{array}{c}0.712 \\
(0.511) \\
\end{array}$ \\
\hline $\begin{array}{l}\text { Fraction outsiders on } \\
\text { board }\end{array}$ & $\begin{array}{l}-0.081^{* *} \\
(0.035)\end{array}$ & $\begin{array}{l}-0.063 \\
(0.057)\end{array}$ & $\begin{array}{l}-0.051 \\
(0.053)\end{array}$ & $\begin{array}{l}-0.087 \\
(0.059)\end{array}$ & $\begin{array}{l}-0.067 \\
(0.188)\end{array}$ & $\begin{array}{l}-0.088 \\
(0.164)\end{array}$ & $\begin{array}{c}0.088 \\
(0.056)\end{array}$ \\
\hline $\begin{array}{l}\text { Fraction of doctors on } \\
\text { board }\end{array}$ & $\begin{array}{l}-0.169^{* * *} \\
(0.037)\end{array}$ & $\begin{array}{l}-0.060 \\
(0.082) \\
\end{array}$ & $\begin{array}{l}-0.028 \\
(0.057) \\
\end{array}$ & $\begin{array}{l}-0.202^{* * *} \\
(0.054)\end{array}$ & $\begin{array}{l}-0.149 \\
(0.267) \\
\end{array}$ & $\begin{array}{l}-0.103 \\
(0.165) \\
\end{array}$ & $\begin{array}{c}0.074 \\
(0.095) \\
\end{array}$ \\
\hline $\begin{array}{l}\text { Fraction of unknown } \\
\text { occupations }\end{array}$ & $\begin{array}{c}0.006 \\
(0.044) \\
\end{array}$ & $\begin{array}{l}-0.039 \\
(0.104) \\
\end{array}$ & $\begin{array}{c}0.036 \\
(0.073) \\
\end{array}$ & $\begin{array}{c}0.015 \\
(0.070) \\
\end{array}$ & $\begin{array}{l}-0.081 \\
(0.195) \\
\end{array}$ & $\begin{array}{c}0.197 \\
(0.180) \\
\end{array}$ & $\begin{array}{l}0.133^{* *} \\
(0.061) \\
\end{array}$ \\
\hline Number of observations & 5127 & 545 & 1757 & 1717 & 257 & 783 & 851 \\
\hline R-squared & 0.13 & 0.11 & 0.09 & 0.14 & 0.40 & 0.23 & 0.09 \\
\hline
\end{tabular}
regressions. All variables except 'newowner,' system and time dummies are lagged.

${ }^{\star * *}$ significant at $1 \%$ level ${ }^{* *}$ significant at $5 \%$ level ${ }^{*}$ significant at $10 \%$ level 


\section{Table 5: Estimated Equations Predicting CEO Turnover}

This table presents the results of logistic regressions predicting CEO turnover. The dependent variable is CEO turnover and is 1 if a change in CEO has occurred since the previous year and 0 if the same person is the CEO. Our sample consists of 486 California acute care hospitals between 1980-1996. Standard errors estimated using a Huber-White sandwich estimator are in parentheses. System is an indicator variable for system affiliation. Excess income margin is the ratio of gross operating and non-operating income to gross revenue. Administrative expenses are total administrative expenses relative to total expenses. Uncompensated care is the sum of bad debt and charity care scaled by gross revenue. All variables except 'newowner,' system and time dummies are lagged.

\begin{tabular}{|c|c|c|c|c|c|c|c|}
\hline Variable & All types & Religious & Nonprofit & Profit & $\begin{array}{c}\text { Govern- } \\
\text { ment }\end{array}$ & District & Teaching \\
\hline New ownership & $\begin{array}{l}1.074^{\star \star \star} \\
(0.192)\end{array}$ & $\begin{array}{l}1.949^{* *} \\
(0.907)\end{array}$ & $\begin{array}{l}1.814^{* * *} \\
(0.423)\end{array}$ & $\begin{array}{l}0.704^{* * *} \\
(0.249)\end{array}$ & $\begin{array}{l}2.762^{* \star *} \\
(0.887)\end{array}$ & $\begin{array}{c}-0.910 \\
(0.991)\end{array}$ & $\begin{array}{l}3.011^{* * \star} \\
(1.133)\end{array}$ \\
\hline System & $\begin{array}{l}0.274^{\star * *} \\
(0.071)\end{array}$ & $\begin{array}{l}-0.680^{* *} \\
(0.300)\end{array}$ & $\begin{array}{c}0.205 \\
(0.139)\end{array}$ & $\begin{array}{l}0.531^{* * *} \\
(0.124)\end{array}$ & $\begin{array}{c}-0.132 \\
(0.306)\end{array}$ & $\begin{array}{c}0.191 \\
(0.239)\end{array}$ & $\begin{array}{c}0.007 \\
(0.197)\end{array}$ \\
\hline Excess income * system & $\begin{array}{c}0.738 \\
(0.773) \\
\end{array}$ & $\begin{array}{c}2.549 \\
(2.215) \\
\end{array}$ & $\begin{array}{c}1.153 \\
(1.918) \\
\end{array}$ & $\begin{array}{c}-0.302 \\
(1.298) \\
\end{array}$ & $\begin{array}{l}-6.039^{* *} \\
(3.139)\end{array}$ & $\begin{array}{l}5.426^{* *} \\
(2.755)\end{array}$ & $\begin{array}{l}7.636^{\star * \star} \\
(3.039)\end{array}$ \\
\hline Excess income & $\begin{array}{l}-2.294^{* * *} \\
(0.584)\end{array}$ & $\begin{array}{c}-0.453 \\
(1.508) \\
\end{array}$ & $\begin{array}{l}-4.076^{\star * \star} \\
(1.196)\end{array}$ & $\begin{array}{l}-2.385^{\star *} \\
(1.064)\end{array}$ & $\begin{array}{c}3.609^{* *} \\
(1.486)\end{array}$ & $\begin{array}{l}-3.913^{* *} \\
(1.752)\end{array}$ & $\begin{array}{l}-6.181^{\text {** }} \\
(2.532)\end{array}$ \\
\hline Uncompensated care & $\begin{array}{c}0.699 \\
(0.571)\end{array}$ & $\begin{array}{l}14.063^{*} \\
(7.620)\end{array}$ & $\begin{array}{c}-1.249 \\
(3.160)\end{array}$ & $\begin{array}{c}0.980 \\
(1.660)\end{array}$ & $\begin{array}{c}0.004 \\
(1.307)\end{array}$ & $\begin{array}{r}6.236^{*} \\
(3.419)\end{array}$ & $\begin{array}{c}0.494 \\
(0.791)\end{array}$ \\
\hline Administrative expenses & $\begin{array}{l}4.181^{* * *} \\
(1.051) \\
\end{array}$ & $\begin{array}{r}7.165 \\
(6.007) \\
\end{array}$ & $\begin{array}{r}3.283 \\
(3.066) \\
\end{array}$ & $\begin{array}{l}3.004^{* *} \\
(1.317) \\
\end{array}$ & $\begin{array}{c}6.671 \\
(5.579) \\
\end{array}$ & $\begin{array}{c}11.526^{\star * *} \\
(4.403) \\
\end{array}$ & $\begin{array}{c}11.662^{\star \star \star} \\
(4.333) \\
\end{array}$ \\
\hline Number of observations & 6162 & 551 & 1794 & 1847 & 267 & 789 & 914 \\
\hline Log likelihood & -3330.03 & -231.08 & -864.75 & -1148.94 & -158.71 & -416.10 & -432.98 \\
\hline
\end{tabular}

${ }^{* * *}$ significant at $1 \%$ level ${ }^{* *}$ significant at $5 \%$ level ${ }^{*}$ significant at $10 \%$ level 


\section{Table 6: Analysis of Hospitals that Exit Early}

This table presents statistics on hospitals that exit our sample prior to the end the sample period. The sample consists of 486 California acute care hospitals between 1980-1996. Excess income margin is the ratio of gross operating and non-operating income to gross revenue. Administrative expenses are total administrative expenses relative to total expenses. Uncompensated care is the sum of bad debt and charity care scaled by gross revenue. All variables except 'newowner,' system and time dummies are lagged.

\section{A. Turnover rates by hospital type:}

\begin{tabular}{|c|c|c|c|c|c|c|c|c|}
\hline \multirow[b]{2}{*}{ Hospital type } & \multicolumn{2}{|c|}{ Entire sample } & \multicolumn{2}{|c|}{$\begin{array}{c}\text { Hospitals Remaining } \\
\text { in for the } 1980-1996 \\
\text { Period }\end{array}$} & \multicolumn{2}{|c|}{$\begin{array}{l}\text { Hospitals Departing } \\
\text { Prior to } 1996^{\mathrm{a}}\end{array}$} & \multicolumn{2}{|c|}{$\begin{array}{l}\text { Hospitals Closing } \\
\text { Prior to } 1996\end{array}$} \\
\hline & \# obs & $\begin{array}{l}\text { CEO } \\
\text { turnover } \\
\text { rate } \\
\end{array}$ & \# obs & $\begin{array}{l}\text { CEO } \\
\text { turnover } \\
\text { rate } \\
\end{array}$ & \# obs & $\begin{array}{c}\text { CEO } \\
\text { turnover } \\
\text { rate } \\
\end{array}$ & \# obs & $\begin{array}{l}\text { CEO } \\
\text { turnover } \\
\text { rate } \\
\end{array}$ \\
\hline Religious & 551 & $17.2 \%$ & 504 & $15.3 \%$ & 47 & $38.3 \%$ & 21 & $42.9 \%$ \\
\hline Nonprofit & 1794 & $20.3 \%$ & 1619 & $20.0 \%$ & 175 & $23.4 \%$ & 103 & $26.2 \%$ \\
\hline Profit & 1847 & $34.6 \%$ & 1466 & $32.3 \%$ & 381 & $43.3 \%$ & 207 & $44.4 \%$ \\
\hline Government & 267 & $36.0 \%$ & 211 & $33.6 \%$ & 56 & $44.6 \%$ & 46 & $41.3 \%$ \\
\hline District & 789 & $24.5 \%$ & 712 & $22.9 \%$ & 77 & $39.0 \%$ & 43 & $48.8 \%$ \\
\hline Teaching & 914 & $19.5 \%$ & 888 & $19.1 \%$ & 26 & $31.0 \%$ & 0 & $\begin{array}{r}\begin{array}{r}\text { Not } \\
\text { applicable }\end{array} \\
\text { a }\end{array}$ \\
\hline All & 6162 & $25.4 \%$ & 5400 & $23.7 \%$ & 762 & $37.7 \%$ & 420 & $40.0 \%$ \\
\hline
\end{tabular}

\section{B. Performance variables by entry/exit status:}

Standard deviations are in parentheses; median values are italicized.

\begin{tabular}{|c|c|c|c|c|}
\hline Variable & Entire sample & $\begin{array}{c}\text { Hospitals } \\
\text { Remaining in for } \\
\text { the } 1980-96 \text { Period }\end{array}$ & $\begin{array}{l}\text { Hospitals Departing } \\
\text { Prior to } 1996^{a}\end{array}$ & $\begin{array}{c}\text { Hospitals Closing } \\
\text { Down Prior to } \\
1996\end{array}$ \\
\hline \#of complete observations & 6162 & 5400 & 762 & 420 \\
\hline System affiliation & 3047 & 2669 & 378 & 186 \\
\hline $\begin{array}{l}\text { Lagged excess income } \\
\text { margin }\end{array}$ & $\begin{array}{c}0.018 \\
(0.086) \\
0.025\end{array}$ & $\begin{array}{c}0.026 \\
(0.071) \\
0.028\end{array}$ & $\begin{array}{c}-0.014 \\
(0.114) \\
0.006\end{array}$ & $\begin{array}{c}-0.011 \\
(0.107) \\
0.002\end{array}$ \\
\hline $\begin{array}{l}\text { Lagged administrative } \\
\text { expenses }\end{array}$ & $\begin{array}{c}0.050 \\
(0.032) \\
0.041\end{array}$ & $\begin{array}{c}0.048 \\
(0.030) \\
0.040\end{array}$ & $\begin{array}{c}0.060 \\
(0.035) \\
0.052\end{array}$ & $\begin{array}{c}0.061 \\
(0.032) \\
0.054\end{array}$ \\
\hline $\begin{array}{l}\text { Lagged uncompensated } \\
\text { care }\end{array}$ & $\begin{array}{c}0.045 \\
(0.059) \\
0.030\end{array}$ & $\begin{array}{c}0.047 \\
(0.061) \\
0.030\end{array}$ & $\begin{array}{c}0.038 \\
(0.044) \\
0.028\end{array}$ & $\begin{array}{c}0.046 \\
(0.052) \\
0.030\end{array}$ \\
\hline
\end{tabular}

${ }^{a}$ This category includes 61 hospitals that close down, 31 that change into a long-term status, and 16 that are acquired. 